\title{
“健康中国”视阈下高职院校学生心理健康教育体系 构建的路径探析
}

\section{于 舒 李志芳}

辽宁金融职业学院

DOI:10.32629/mef.v1i1.9

[摘 要] 在“健康中国”这个大背景下, “健康校园”的建设成为其中的重要组成部分, 随着改革开放的深入发展, 多层次、 多元化人才的需求变大, 更需要人才具备强大的心理素质来应对多变的竞争环境。而对于高职院校学生来说, 更加面临 着严峻的就业和创业挑战, 作为人才培养的重要阵地, 高职院校要积极探索学生心理健康教育体系构建的基本路径。本 文通过研究分析高职院校学生心理健康教育体系构建的重要意义, 以及心理健康教育体系现状, 提出高职院校学生心理 健康教育体系构建的基本路径。

[关键词] 健康中国; 高职院校; 心理健康教育体系; 基本路径

高职院校学生心理健康教育体系的构建是建设“健康 校园”的重要因素之一, 2016年国务院颁发的《“健康中国 2030 ”规划纲要》中指出: “健康是促进人的全面发展的必 然要求, “身”与 ‘心”两手抓, 两手都要硬, 加强心理健康服 务体系建设和规范化管理刻不容缓。”可见, 心理健康教 育成为构建 “健康中国” 的重要任务。高职院校作为培养 人才的重要阵地, 有其特殊性, 高职院校的学生在毕业之 际面对就业和创业的问题, 随着我国教育层次的大幅度 改革, 高职院校的学生的就业竞争力受到严峻的挑战, 要 适应复杂的社会要求, 就必须要具备强大而完善的综合 素质, 如何完善高职院校学生的综合素质, 除了培养学生 德勤能技的要素之外, 心理健康也将成为高职院校学生 提高综合竞争力的关键, 构建完善的心理健康教育体系具 有重要的意义。

\section{一、高职院校学生心理健康教育体系构建的重要意义}

(一)高职院校学生心理健康教育体系构建益于提高 学生的适应社会发展需要的能力。随着社会发展的规范 性、改革性、创新性等现代化特征的显现, 对心理健康的关 注也逐步凸显出来。高职院校的学生同样担负着建设国 家的重任, 是社会、家庭、学校共同培养的主要群体, 根据 近几年毕业大学生学历就业的情势分析, 高职院校的学 生面临着更加严峻的就业形势, 一些重要职位或者管理 岗位被高学历人才占据, 高职院校的学生只能从事一些具 体事务性或者重复性的工作, 这在无形之中就给高职院校 的学生的心理上增添了就业的压力和屏障, 而早在两千五 百年多年前, 孔子就根据自己的观察评定学生的个体差
异, 把人分为中人、中人以上和中人以下三个类别, 并指 出, “中人以下, 不可以语上也; 中人以上, 可以语上也。”社 会正在处于速度发展的关键期, 构建心理健康教育体系有 助于提高学生的适应社会发展需要的能力, 才能在未来就 业竞争中占据一席之地, 使高职院校的学生的心理健康不 断优化,切实培养全面发展的优秀人才。

(二)高职院校学生心理健康教育体系构建益于优化 学生的心理健康水平。心理健康教育体系为学校的健康 教育提供了一个新的通道, 注重对学生心理素质的培养和 消极行为的预防, 而不是事后的 “补救”。关于心理健康, 第 三届国际心理卫生大会曾认定心理健康的标志主要是四 个方面: “一是身体、智力、情绪十分和谐; 二是能够适应环 境, 人际关系中彼此能谦让; 三是拥有幸福感; 四是能充分 发挥自己的能力, 过着有效率的生活。”而当心理活动处于 一种不在常规的状态和过程中, 就会出现“心理不健康” 的 状态, 从而影响着个体生存发展和生活质量, 而这种失衡 状态是可以提前预防的, 构建心理健康教育体系有助于预 防和发现 “不健康心理” 的出现, 更好地实现学生的 “健康 心理”稳定发展。

(三)高职院校学生心理健康教育体系构建益于树立 健康的生活观。健康的生活观是每个学生走出校门时应 具备的环境适应能力。人为了自我发展和完善必须要适 应环境的变化。健康的生活观是为了追求美好的幸福感, 而幸福感是来自于自己的自信和美德。三国时期, 刘劭著 有《人物志》一书, 在该书中, 刘劭将人分类为豪杰、圣贤、 拘憟、傲荡, “心大志大者豪杰之伦也; 心小志大者圣贤之 
伦也; 心小志小者拘憟之伦也; 心大志小者傲荡之伦也。” 由于生存环境的变化十分剧烈, 人在处理问题的过程中 不可能做到一如既往的 “积极”, 人对它无能为力时, 面对 它只有忍耐和蹈光养晦, 这是 “消极适应”, 其内在意义含 有积极的因素。一个人能否很快的适应生活环境, 并以此 保持心理平衡, 往往标志着一个人的是否具备健康的生活 观。

\section{二、高职院校心理健康教育体系现状分析}

目前, 高职院校设立专门的心理咨询室对学生进行 心理疏导和教育,一般采取心理讲座、调查问卷等方式了 解学生心理现状并进行心理健康教育, 往往这种教育方 式处于被动的境地, 心理健康教育体系虽已具备维形, 但 仍需亟待完善。

(一)学生对心理健康教育认识不足。由于绝大多数 学生认为有心理问题是一件难以启齿的事情, 通常采取拒 绝回避的态度对待心理问题, 久而久之, 心理问题会愈来 愈严重。其实 “心理健康” 这一概念相对应的最恰如其分 的概念, 只有 “心理不健康”, 而这两者都属于正常心理范 围。心理健康是一种常规的心理状态, 它在特定的时段内 展现着正常功能, 心理健康是指在正常条件下, 是在个体 与内外生存环境的相互作用中实现的。倘若个体或者内 外生存环境发生了特殊的变化, 这种正常的心理状态可 能被打破, 心理活动就可能偏离常规的健康常模, 这时的 心理就处于一种失重的状态, 而不在正常范围之内的心理 活动被称为“心理不健康”。因此, “心理健康” 和“心理不健 康” 是在一定的常规条件下相互转化的, 不是一成不变的。 而学生并不知道这一复杂的心理变化过程, 只是单纯的认 为自己的心理有问题, 讳疾忌医, 如果普通的心理问题得 不到及时治疗, 很可能导致成为精神病性心理问题。目前 严峻的问题是要让学生真正理解心理健康教育是为了让 他们了解自己的心理现状。

(二)专职心理健康教育师资队伍发展滞后。据调查 统计, 大多数高职院校的心理健康教育师资队伍在性别比 例、学历、培训及继续教育等方面存在滞后的现象。高校辅 导员中取得心理咨询师资格证的人员比例较低, 这对及时 对有心理问题的学生进行干预和引导存在很大的难度, 在 与学生进行心理疏导和教育中处于被动的位置, 学生很难 与教师敞开心扉, 不利于开展学生的教育工作。还有很多 院校没有专职的心理健康教育教师, 而采用兼职其他学科 的教师作为心理健康教师, 这对构建心理健康教育体系仍
是需要亟待解决的问题。

(三)对于新生心理排查不够具体。大多数学校在新 生人学时进行心理普查, 但是普查的方式是通过电脑答 题, 得到的结果是合格与不合格, 并没有指向性的提示和 具体的指导, 在学生答题完毕后, 不能根据题目等有效指 标进行合理的改正, 也没有得到相应问题的反馈, 显得心 理测试只是人学程序的一部分, 导致大多数学生对于心理 普查不重视, 检测结果没有重要的实际意义, 这一问题有 待于进一步改进。

(四)心理咨询的软硬件条件匮乏。大多数学校没有 注重心理咨询室的建设, 只是安排一个单独的房间作为心 理咨询室, 房间设备陈旧, 反而让求助者情绪得不到放松。 每一个求助者的内心都是存在戒备心理的, 不会轻易地将 心声祖露, 只有适应了这个环境, 并接受了心理咨询教师 的建议才会说出自己的心理问题,因此,心理咨询的环境 显得尤为重要, 一个心理咨询室能否满足求助者对私密性 和保密性的要求, 会影响到求助者对心理咨询师的信任和 开放程度,影响心理咨询的效果。

\section{三、高职院校学生心理健康教育体系构建的基本路径}

(一)将心理健康教育体系的构建摆上学校整体工作 的重要日程。学生是学校发展的根本大计, 高职院校要更 加重视心理健康教育的重要性, 影响学生心理不稳定的因 素有很多, 需要拓宽心理健康教育的广度。高职院校应该 建立专门的心理健康教育中心, 设立专职心理咨询师、兼 职心理咨询师、精神病学专家等。学校还要建立详细的学 生心理档案, 对来访的学生记录他们的兴趣爱好、人格特 征、健康状况等内容, 以便做好心理问题的随访工作。每个 学生的心理成长是一个漫长的过程, 在不同的时期表现出 来的特征往往具有连续性, 通过档案的建立可以更加有效 地采取对应的心理咨询方法和治疗措施。

(二)加强高职院校心理健康教育师资力量的培养力 度。根据学校的学生实际状况, 建立完善的心理学师资的 供需平衡机制, 要建立起适应高职院校发展特点的专业教 育、岗位教育和继续教育有机衔接的心理学师资培训体 系。完善教学一线工作人员的心理继续教育, 鼓励辅导员 队伍取得心理咨询师资格证书, 加大心理咨询教师的培训 力度, 推进心理咨询师的专业化。建立心理健康教育学习 平台, 运用新媒体技术宣传心理健康教育的重要性, 普及 心理健康知识, 使学生获得对生活和学习有益的心理健康 预防知识。 
(三)加强利于构建心理健康教育体系的校园环境文 化建设。校园环境是学生生活、学习的重要活动场所, 优 雅的校园环境有助于学生身心愉快, 通过建设主题大厅、 文化长廊、校区沙盘等文化设施, 规范道路、楼宇名称标识 等途径, 打造校园人文景观文化。大力加强图书馆、档案 馆、校史馆、体育馆、运动场等文化基础设施建设, 鼓励学 校各系院持续开展特色文化墙建设, 积极健康的校园环 境能够有效促进学生的身心健康和谐发展, 也是建设 “健 康校园”的重要基础。

(四)加强心理咨询室的整体设施建设。良好的心理 咨询室有助于心理咨询的实施, 在心理咨询室建设方面, 要参照国家普通高等学校心理咨询室建设标准, 色调温 和简单大方, 高职院校的心理咨询室的面积要适宜, 灯光 要柔和并可以进行调节阴暗, 要配备两三张舒适的、有靠 背和扶手的椅子, 墙上要悬挂心理咨询范围、来访者须知、 心理健康教育教师简介等内容, 室内的物品要齐全, 要配 备饮水设备、电脑、电话、相关的杂志读物等; 确保环境的 舒适, 使来访学生能够尽快的适应环境打开心扉、吐露心 声, 以便心理健康教师进行干预和治疗。

十九大报告中再次指出实施 “健康中国” 战略, 在这
一大背景下, 高职院校作为教育的重要阵地, 要高度重视 学生的心理问题, 全面引进专业人才, 把构建心理健康教 育体系落在实处, 通过开展校园心理剧、知识竞赛、心理健 康讲座、阳光体育活动等一系列活动, 有助于营造积极、健 康、和谐的“健康校园”。

\section{[参考文献]}

[1]吴文博. “健康中国”视域下的高校大学生心理咨 询模式的构建研究 [J/OL]. 黑龙江教育学院学报,2018,(10). 96-98.

[2]莫冰莉,李忆湘.高校健康校园平台系统评价体系 构建研究 [J].城市学刊,2017,38(02).91-95.

[3]黄建, 朱健. 高校心理健康教育理论与实践 [ M ] . 上海: 上海交通大学出版社, 2015:79.

[4]中国心理卫生协会. 心理咨询师 $[M]$. 北京: 民 族出版社, 2015:35-36.

作者简介: 于舒 (1982-), 女, 汉族, 山东掖县人, 副研究 员,硕士, 研究方向: 高等职业教育研究。

基金项目: 本文系 2018辽宁省规划办一般课题“健康中国 背景下高职院校健康校园指标体系研究” 阶段研究成果 (编号:JG18EB115)。 